\title{
POJAM HIBRIDNOG RATA
}

\author{
Nenad Cvetković* \\ Ministarstvo odbrane Republike Srbije \\ Mitar Kovač ** \\ Univerzitet Edukons, Fakultet za projektni i inovacioni menadžment, \\ Beograd \\ Branko Joksimović \\ Ministarstvo odbrane Republike Srbije
}

U radu se analizira istorijski i praktični aspekt pojma hibridni rat, nakon čega se kroz analizu postojećih teorijskih razmatranja o hibridnom ratu pokušava doći do određene definicije pojma, kojom bi trebalo da se odredi sadržaj, obim, karakter, nosioci i cilj ove vrste sukoba.

Ključne reči: rat, sukob, hibridni rat

\section{Uvod}

storiju civilizacije, pored bogate kulture, tradicije, stvaralaštva i pozitivnih događaja, ka-

rakterišu i stalni sukobi društvenih grupa, zajednica ili država. Ti sukobi su se manifestovali kroz različite oblike, a u najozbiljnijem kao oružani sukobi ili ratovi. Termin rat je vremenom, od poimanja sa većim oružanim sukobom između država, počeo da se koristi i u izražavanju sukoba u drugim oblastima društvenog delovanja, uz korišćenje prideva za formiranje sintagmi - hladni rat, specijalni rat, totalni rat, višedimenzionalni, neograničeni, hibridni rat.

Hibridni rat je termin čija upotreba je doživela poseban intenzitet u poslednjih nekoliko godina, a sam termin se pojavio početkom 21. veka. lako je zaključak većine autora da on ne označava ništa novo u odnosu na neke druge slične pojmove, do jedinstvene ili opšte prihvaćene definicije, se nije došlo. Karl Fon Klauzevic je govorio da „rat u svakom periodu ima nezavisnu formu i nezavisne uslove, i, zbog toga, svaki period mora da ima svoju nezavisnu teoriju o ratu". Da li početak 21. veka i aktuelni ratovi i krize zaslužuju novi pojam?

$\mathrm{U}$ radu ćemo istražiti istorijski kontekst i hronologiju korišćenja termina hibridni rat od njegovog pojavljivanja 2001. godine, do danas. Zatim ćemo analizirati praktičan aspekt korišćenja termina, motiva i mogućih razloga za njegovu upotrebu. U stručnoj javnosti postoje različita mišljenja o sadržaju hibridnog rata, koriste se različiti pojmovi i termini, pa ipak, može se primetiti saglasnost oko toga da je hibridni rat kombinacija neoružanih i oružanih oblika ugrožavanja. O kojim se oblicima radi takođe će biti reči.

Cilj rada je da se analizom postojeće teorijske građe dođe do prihvatljive definicije pojma hibridni rat. U tome će nam pomoći istraživanje postojećih definicija ovog pojma a takođe i slično upotrebljavanog pojma hibridne pretnje, zatim poimanja rata i sukoba

\footnotetext{
*Potpukovnik Nenad Cvetković, nenad.cvetkovic@mod.gov.rs.

** Dr Kovač Mitar, general u penziji, redovni profesor, Fakultetu za projektni i inovacioni menadžment
} 
kao društvenih odnosa. Rukovodićemo se jednostavnim pitanjima šta je hibridni rat, ko ga vodi, protiv koga, na koji način, gde ga vodi, zbog čega i sa kojim ciljevima. Odgovori na ova pitanja treba da nam omoguće definisanje same pojave, određivanje obima i sadržaja pojma, njegovog odnosa sa ostalim sličnim pojmovima u okviru teorije ratne veštine.

\section{Istorijski aspekt pojma hibridni rat}

Period pojave termina „hibridni rat" se veže za početak XXI veka, vreme kada je nakon perioda Hladnog rata, na svetskoj sceni ostala jedna globalna supersila, SAD, a od nekih autora se pretpostavljalo da će doći do „kraja istorije ", da dolazi vreme bez većih ratova, gde će se problemi rešavati demokratskim putem i dogovorima. Međutim, stvarnost je bila drugačija. Tokom 90-ih godina prošlog veka i početkom XXI veka, svet se susreće sa većim brojem manjih, građanskih ratova, i ratova velikih sila protiv manjih država.

Hibridni rat se kao termin pojavio prvi put u master radu Vilijama Nemeta (William Nemeth) - „Future war and Chechnya: a case for hybrid warfare“, 2002. godine. ${ }^{2}$ On je analizirao ratove u Čečeniji, Ruskoj Federaciji, tokom 90 -ih godina i izneo tezu da će budući ratovi biti uglavnom hibridni poput rata u Čečeniji, a da će čečenski način borbe i gerile, biti njegov model. $U$ tom trenutku termin nije bio dovoljno prihvaćen i bio predmet daljih razmatranja.

Nakon terorističkog napada na SAD, 11. septembra 2001. godine, najpre ova zemlja a zatim i njeni partneri iz NATO, ulaze u ratove u Avganistanu i Iraku. Vojno superiorniji i nadmoćniji od svojih protivnika, uspostavljaju svoje vojno prisustvo u ovim zemljama, ali uporedo se susreću i sa mnogobrojnim problemima. Protivnici američkoj vojsci postaju manje oružane grupe koje primenjuju partizanski, gerilski način ratovanja, izbegavaju frontalne ili veće sukobe, sakrivaju se među stanovništvom ili imaju njihovu pomoć duboko u teritoriji, disperzivno se razmeštaju čak i po gradovima u vidu manjih ćelija, izvode napade na logističke lance, patrolne rute, ekonomske resurse, u gradovima angažuju snajperiste i samoubice. Koriste jednako ili približno moderno pešadijsko oružje kao njihov neprijatelj, a organizuju komunikaciju koja je za koalicione snage teško uhvatljiva. U ovakvim uslovima, teoretičari, pre svega u SAD a kasnije i u Zapadnoj Evropi, u javni diskurs polako unose termin hibridni rat ili hibridne pretnje, kada govore o oblicima ratova u 21. veku. Pri tome ga koriste iz ugla oružanih snaga SAD, kako bi opisali pretnje ili stanje u kome se nalazi njihova vojska u zemljama u kojima ratuju.

Frenk Hofman (Frank G. Hoffman) i Džejms Matis (James N. Mattis) u kratkom članku objavljenom 2005. godine - „Future Warfare: The Rise of Hybrid Wars “ ${ }^{3} \mathrm{U}$ tom smislu oni tadašnje aktuelne pretnje američkoj vojsci u Iraku i Avganistanu (terorizam, gerilsko ratovanje, informacione operacije, delovanje organizovanih kriminalnih grupa) nazivaju hibridnim a sintezu različitih oblika neprijateljskog delovanja u budućim ratovima, hibrid-

\footnotetext{
${ }^{1}$ Fukujama F.: End of history and last man, The free press, Macmillan, New York, 1992.

${ }^{2}$ Nemeth W.J.: Future war and Chechnya: a case for hybrid warfare, Naval Postgraduate School, Monterey, California, 2002; https://calhoun.nps.edu/bitstream/handle/10945/5865/02Jun_Nemeth.pdf.

${ }^{3}$ Mattis J., Hoffman F.: Future Warfare: The Rise of Hybrid Wars, Proceedings 131, 11, Vašington, 2005.
} 
nim ratom. Ubrzo Frenk Hofman u svom delu „Conflict in the $21^{\text {st }}$ Century: the Rise of Hybrid Wars “A ${ }^{\star A}$ postavlja temelje onoga čime će se pre svega američka naučna javnost, a zatim i ona u Velikoj Britaniji, Izraelu i nekim zemljama zapadne Evrope baviti u narednim godinama, raspravljajući o modernim ratovima.

I dok su određeni autori bili slobodni da koriste termin hibridni rat ${ }^{5}$ ili hibridne pretnje ${ }^{6}$, zvanični državni organi u SAD, a pre svega Ministarstvo odbrane, su se uzdržavali od upotrebe ovog termina u zvaničnim dokumentima, sve do 2010. godine. U četvorogodišnjem izveštaju ${ }^{7}$, Ministarstvo odbrane SAD je pomenulo po prvi put izraz hibridni kako bi ukazalo na povećanu složenost rata u današnje vreme koji uključuju mnogo aktera i brisanje granice u odnosu na tradicionalne sukobe. Zatim se 2011. godine, u američkim doktrinarnim dokumentima, „U.S Army Field Manual 5-0“ 8 i „U.S Army Field Manual 3-0“ 9 definišu moguće hibridne pretnje kao dinamička kombinacija konvencionalnih, neregularnih, terorističkih i kriminalnih resursa, prilagođeni da se suprotstave tradicionalnim prednostima koje ima američka vojska. Ministarstvo odbrane Velike Britanije je 2010. godine u svom dokumentu „Future Character of Conflict Paper" diskutovalo i iznelo da će budući konflikti imati hibridan karakter. ${ }^{10}$ Slična diskusija i narativ o hibridnom ratu ili hibridnim pretnjama, u smislu problema sa kojima se susreću SAD, se nastavlja na ovom, može se reći taktičkom ili operativnom nivou opisivanja problema na samom bojištu, sve do 2014. godine.

Tokom 2014. godine nastaje kriza u Ukrajini, smena političke vlasti, oružana pobuna stanovnika na istoku zemlje, zatim otcepljenje Krima i prisajedinjavanje Ruskoj Federaciji. Tada se, pre svega od strane političara i pojedinih analitičara u zemljama istočne Evrope (Poljska, Ukrajina, Estonija, Letonija, Litvanija), skandinavskim zemljama i Velikoj Britaniji, delovanje Rusije prema Ukrajini počinje opisivati kao hibridni rat. U sadržaj takvog rata su uvrstili niz vojnih i nevojnih aktivnosti, specijalne operacije ruske vojske, sajber rat, informativni rat, finansijski i socio-ekonomski pritisak, političku borbu, itd. Posebno je u tu svrhu korišćen rad ruskog generala Valerija Gerasimova, tadašnjeg Načelnika Generalštaba Vojske Ruske Federacije, koji je on objavio 2013. godine (interpretiran u javnosti zemalja Zapadne Evrope i SAD kao nova ruska doktrina, tzv. „Gerasimova doktrina“). On je u svom radu pod nazivom „Značaj nauke je u predviđanju“11 izneo strateško

\footnotetext{
${ }^{4}$ Hoffman F.: Conflict in the 21st Century: the Rise of Hybrid Wars, Potomac Institute for Policy Studies, Arlington, Virginia, 2007; www.potomacinstitute.org/images/stories/publications/potomachybridwar0108.pdf.

${ }^{5}$ Margaret Bond (Margaret S. Bond), pukovnik u vojsci SAD, u svom autorskom izveštaju navodi da će rat sledećeg veka obuhvatiti neku vrstu hibridnog rata. (Bond S.M.: Hybrid War: A New Paradigm For Stability Operations In Failing States, Strategy Research Project, U.S. Army War College, 2007, str. 3; http://www.worldinwar.eu/wp-content/uploads/2017/09/ ADA468398-1.pdf).

${ }^{6}$ Rasel Glen (Russell W. Glenn) je 2009. godine definisao hibridne pretnje kao kombinaciju istovremeno primenjenih (1) političkih, vojnih, ekonomskih, društvenih i informativnih sredstava i (2) konvencionalnih, neregularnih, terorističkih i kriminalnih sredstava.

(Glen R.W.: Thoughts on Hybrid Conflict, Small Wars Journal, 2009, str. 2, www.smallwarsjournal.com/blog/journal/).

${ }^{7}$ Quadrennial Defense Review, Ministarstvo odbrane SAD, Vašington, 2010, str. 8; https://www.defense. gov/Portals/1/features/defenseReviews/QDR/QDR_as_of_29JAN10_1600.pdf.

${ }^{8}$ Field Manual 5-0: The Operations Process, Headquarters, Department of the Army, Washington, 2011.

${ }^{9}$ Field Manual 3-0: The Operations Process, Headquarters, Department of the Army, Washington, 2011.

${ }^{10}$ Future Character of Conflict, HQ Land Forces, Ministarstvo odbrane V.B., , London, 2010, s. 13.

${ }^{11}$ Gerasimov V.: Cennostb nauki v predvideni, Vojno-industrijski glasnik, Moskva, mart 2013; https://vpknews.ru/sites/default/files/pdf/VPK_08_476.pdf.
} 
razmišljanje o vođenju totalnog rata, kao ratu današnjice, u okviru koga su se pravila ratovanja promenila, pa je upotreba nevojnih sredstava radi dostizanja političkih i strateških ciljeva dobila mnogo više na značaju od upotrebe klasičnih vojnih. Naveo je da je pristup ratu danas gerilski i rasprostranjen na širokom frontu, sa različitim akterima i metodama od hakera na računarskim mrežama, medijima, ekonomistima do korišćenja obaveštajnih službi, specijalnih vojnih snaga i sl.

Dotadašnja teorijska i naučna rasprava, koja se vodila u naučnim krugovima, počinje da se institucionalizuje i to od strane NATO-a i EU. Na samitu u Velsu su definisana dva strateška izazova za NATO, drugačija po svojoj formi i ispoljavanju, Ruska Federacija na Istoku i teroristička grupa ISIL na Jugoistoku. Tadašnji komandant NATO snaga, general Filip Bridlav (Filip M. Breedlove), je istakao da se ova dva izazova sastoje od različitih aktera, sa različitim formama delovanja u okviru modernog hibridnog ratovanja. ${ }^{12}$ lako se u okviru NATO nije došlo do jedinstvene definicije hibridnog rata, u nekoliko dokumenata a i izjava zvaničnika se moglo zaključiti da se pod njim podrazumevaju različite metode delovanja protivnika u okviru tzv. „DIMEFIL“ spektra - diplomatske, informacione, vojne, ekonomske, finansijske, obaveštajne i pravne metode. ${ }^{13}$

U Ruskoj Federaciji je takođe počelo da se govori o hibridnom ratu (na ruskom jeziku: гибридная война), i to pretežno kao odgovor na diskusiju na Zapadu. Na nekoliko konferencija je zaključivano i da: hibridni rat predstavlja podrivanje moći neprijatelja kao politički cilj rata; u njemu se pretežno koriste nevojne metode delovanja radi uticaja na javno mnjenje i političku elitu protivnika; ima za cilj podrivanje legitimiteta postojeće vlasti, kako bi se ista zamenila vlašću na koju će se imati veći uticaj; njime se utiče na kulturne i duhovne vrednosti protivnika a zatim i na materijalne. I pored toga što je većina autora zaključila da današnji ratovi, pa i tzv. hibridni, nisu samo vođenje ratnih operacija već imaju i svoju ekonomsku, medijsku, kulturnu, finansijsku komponentu, od strane vojnih zvaničnika i državnih organa Rusije, terminologija sa pridevom hibridni nije usvojena niti definisana nekim državnim dokumentima.

Andrej Koribko, ruski novinar i publicista, je „obojene revolucije“ u zemljama kao što su Ukrajina, Libija, Egipat, Sirija, od kojih su neke prerasle i u oružane sukobe nedržavnih oružanih formacija protiv zvaničnih oružanih snaga tih država, ocenio kao hibridni rat koji sprovode SAD i određene zemlje Evrope. U svojoj knjizi koju je objavio 2015. godine - „Hibridni ratovi: Indirektni adaptivni pristup promeni režima“ ${ }^{15}$, je kao elemente ovakvog hibridnog rata naveo: diplomatiju, informatičke napade, ekonomski rat, informativni rat i propagandu, podršku lokalnim grupama, neregularne oružane snage (terorizam), regularne oružane snage i specijalne jedinice.

\footnotetext{
${ }^{12}$ Lasconjarias G., Larsen A.J.: Nato's response to hybrid threat, NATO Defense College, 2015; Wales Summit Declaration, NATO, Vels, 2014; www.nato.int/cps/en/natohq/official_texts_1 2964.htm.

${ }^{13}$ DIMEFIL - Diplomatic, Information, Military, Economic, Financial, Intelligence and Law. (Erdal C., Murat A., Basar K.: Modeling and Simulation for Hybrid Environments, NMSG Conference, Bukurešt, 2016; www.sto.nato.int/publications/.../MP-MSG-143-08P.pdf).

${ }^{14}$ Gibridnaя voŭna - Ponяtiǔ, Vestnik, MAGIMO Univerzitet, Moskva, istraživački članak, intervju sa Ofer Fridmanom, profesorom na Kraljevskom koledžu u Londonu, 2016; https://cyberleninka.ru/article/n/gibridnayavoyna-ponyatiy.

${ }^{15}$ Koribko A.: Hybrid Wars: The Indirect Adaptive Approach To Regime Change, Narodni univerzitet Rusije, Moskva, 2015; https://orientalreview.org/wp-content/uploads/2015/08/AK-Hybrid-Wars-updated.pdf..
} 
Radi razmatranja istorijskog aspekta ovog pojma, potrebno je napomenuti i da načini ratovanja koje se danas opisuje pridevom hibridni, nisu novi za čovečanstvo, i da istorijski primeri dosežu do antičkog doba. U svetlu hibridnog ratovanja kako su ga na Zapadu gledali do krize u Ukrajini, mogu se naći primeri tzv. hibridnih protivnika u vreme antičkog Rima, kada je nasuprot Rimskoj vojsci postojalo zajedničko delovanje regularne vojske protivnika, kriminalnih bandi, plaćenika, čiji je način borbe bio od frontalnih sukoba do zaseda, atentata. Tokom Drugog svetskog rata, Sovjetska armija je na Istočnom frontu organizovala i sinhronizovala borbu partizanskih snaga u pozadini nemačkih snaga, koje su delovale sve vreme po linijama komunikacija i snabdevanja protivnika. U Vijetnamskom ratu je postojao raznovrsni i združeni otpor Armije Severnog Vijetnama, neregularnih snaga i Vijet Konga, vojno superiornijem protivniku kakav su tada bile oružane snage SAD. Takođe, tokom Hladnog rata i nastupanja velikih sila, SAD i SSSR, jedne protiv druge, kako u direktnom sukobu, tako i preko uticaja na druge manje države, ispoljile su se metode delovanja na ekonomskom, medijskom, socijalnom, obaveštajnom polju, kakve danas prepoznajemo u tzv. hibridnom ratovanju određenih zemalja.

\section{Praktični aspekt pojma hibridni rat}

Istorijski kontekst nastanka pojma hibridni rat je bitan sa stanovišta razmatranja njegovog praktičnog aspekta, tj. analize uzroka, motiva i potreba za njegovom upotrebom od strane akademske i stručne javnosti, a zatim i usvajanja i korišćenja od strane institucija kakve su Evropska unija ili NATO. Generalni sekretar NATO, Jens Stoltenberg je izjavio da je „prvi primer hibridnog rata koji nam je poznat verovatno bila upotreba Trojanskog konja u Trojanskom ratu, što znači da smo ga već videli“ ${ }^{16}$ Ako je sadržaj već poznat, postavlja se pitanje zašto se koristi novi semantički izraz a ne neki postojeći, kao što je recimo specijalni rat?

$U$ već pomenutom zborniku radova „NATO's response to hybrid threats “17, uređivači zbornika, Guillaume Lasconjairas i Jeffrey Larsen, navode da hibridni pristup ratu nije nov i da je to generalni zaključak svih knjiga, članaka, radova objavljenih od strane stratega, civilnih profesora, vojnih istoričara, različitih stručnjaka. Ipak, podržavaju stav i citat Pitera Mansora (Peter Mansoor) - „iako je malo toga novo u hibridnom ratu kao konceptu, koristan je način razmišljanja o ratovima u prošlosti, sadašnjosti i budućnosti“. ${ }^{18}$

Problemi kontrole teritorije koji možda nisu bili očekivani za SAD u Iraku i Avganistanu, ili Izraela u Libanu, su uzrokovali određenu diskusiju teoretičara koji se bave vojnim pitanjima a koji su, zbog raznovrsnosti, nepredvidivosti delovanja protivnika na bojnom polju, ali i u informativno-socijalno-ekonomskoj sferi, počeli da upotrebljavaju pridev hibridni. lako se malo njih upuštalo u semantičko značenje simbola hibridni, u većini jezika on se koristi da označi mešavinu ili kombinaciju nečega, pa je to verovatno bio povod da se prihvati i u opisivanju različitosti, kombinacija više metoda delovanja protivnika. Čini

\footnotetext{
${ }^{16}$ Stoltenberg J.: „Zero-Sum? Russia, Power Politics, and the post-Cold War Era“, Brussels Forum, 2015; https://www.nato.int/cps/su/natohq/opinions_118347.htm.

${ }^{17}$ Lasconjairas G. i Larsen J.: Nato`s response to hybrid threat, NATO Defense College, 2015.

${ }^{18}$ Murray W. i Mansoor P.: Hybrid Warfare: Fighting Complex Opponents from the Ancient World to the Present, Cambridge University Press, New York, 2012.
} 
se da je osnovni motiv za upotrebu termina hibridni rat, želja da se naglasi značaj aktuelnih bezbednosnih pretnji i karakter sukoba u kojima učestvuju ili su izložene određene zemlje. Korišćenje termina od strane nekih autora je verovatno bilo motivisano i željom da se iznedri nešto novo, različito u odnosu na dotadašnje „po pakovanju“ (a slično po sadržaju), čime bi se privukla pažnja stručne javnosti.

Korišćenje novog naziva za današnje ratove i agresije, od strane političara i vojnih zvaničnika, utiče na bolju percepciju od strane javnog mnjenja, a koje je uvek bitno radi odobravanja i saglašavanja sa određenim odlukama državnih organa. Termin hibridni rat je koristan sa tačke gledišta državnih zvaničnika jer sa jedne strane uzdiže pitanje u očima javnosti a sa druge omogućava bezbednosnim strukturama da obuhvatnije i odgovornije planiraju i razvijaju odgovore u kriznim situacijama.

NATO je koncipirao hibridni rat posmatranjem i objašnjavanjem aktivnosti Ruske Federacije u sukobu sa Ukrajinom, a koje nisu bile klasične vojne (uz zvaničnu upotrebu oružanih snaga RF). Ovo se naravno nije uklapalo u koncept ratovanja za koji NATO postoji i za koji je osposobljen, sukobe pre svega vojnih elemenata nacionalnih država, pa je termin hibridni rat, iskorišćen da se opiše sve ono što nije spadalo u obrazac neprijateljskog delovanja koji NATO prepoznaje. Istovremeno, za jačanje međusobnih veza zemalja članica, jačanja njihovih bezbednosnih kapaciteta, saradnje na svim nivoima, poželjno je pre svega imati neprijatelja, a zatim i razviti koncept rata koji bi bio verovatan. Novi termin za moguće pretnje sigurno dodatno naglašava značaj daljeg zajedničkog delovanja država članica. Posebno se tu daje naglasak na razmeni obaveštajnih informacija, održavanju vojnih vežbi uglavnom u zemljama NATO u Istočnoj Evropi. Pogodno je to činiti ako u pozadini imate teoriju o hibridnom ratu koji vodi ta zemlja.

Termin ima svoju političku dimenziju, posebno od zaoštravanja odnosa SAD, nekih evropskih zemalja i Rusije, te služi da alarmira, pre svega zapadnu javnost, kroz semantički novi izraz. Teško se može preći preko činjenice da je hibridni rat doživeo svoje redizajniranje značenja a zatim i masovnu upotrebu i diskusiju upravo tada kada su se odnosi velikih sila zaoštrili i došli skoro na nivo na kojem su bili u vreme hladnog rata. Ovoga puta su se SAD i evropske zemlje u NATO-u opredelili za korišćenje drugačijeg termina.

Termin naglašava kompleksnost globalnog i regionalnog bezbednosnog okruženja. Objedinjuje različite bezbednosne pretnje kao što su terorizam, migracije, organizovani kriminal, obaveštajne službe, ekonomske pritiske, medijsku propagandu i dezinformisanje, i naglašava činjenicu da one potiču od jednog nosioca, što u krajnjem omogućava bolje razumevanje bezbednosne situacije, kako za javno mnjenje tako i za državne organe koji tome treba da se suprotstave. Termin takođe treba da alarmira državne organe na svim nivoima i u svim oblastima, na definisanje strategijskih, operativnih pa i taktičkih planova radi suprotstavljanja eventualnim hibridnim oblicima agresije.

\section{Sadržaj hibridnog ratovanja}

Sadržaj rata čine metode, načini i oblici delovanja sukobljenih strana u nastojanju da ugroze jedna drugu. $U$ tabeli 1. je dat pregled sadržaja hibridnog ratovanja prema autorima i literaturi koja nam je bila dostupna. 
Tabela 1 - Pregled sadržaja hibridnog ratovanja u literaturi

\begin{tabular}{|c|c|c|c|c|c|c|c|c|}
\hline $\begin{array}{l}\text { Izvor I } \\
\text { Sadržaj }\end{array}$ & $\begin{array}{c}\text { Frank } \\
\text { Hoffman }\end{array}$ & $\begin{array}{l}\text { Russell } \\
\text { Glenn }^{19}\end{array}$ & $\begin{array}{l}\text { MO } \\
\text { VB }^{20}\end{array}$ & NATO $^{21}$ & $\begin{array}{l}\text { "Jagello } \\
\text { 2000“" } \\
\text { Češka }\end{array}$ & $\underset{\text { Koribko }^{23}}{\text { Andrej }}$ & $\begin{array}{l}\text { "MCDC } \\
\text { Project }{ }^{424}\end{array}$ & $\begin{array}{c}\text { Munich } \\
\text { Security } \\
\text { Report } \\
2015^{25}\end{array}$ \\
\hline $\begin{array}{l}\text { Političke } \\
\text { metode }\end{array}$ & & $x$ & $\bar{x}$ & $\bar{x}$ & $\bar{x}$ & $\bar{x}$ & $\bar{x}$ & $\bar{x}$ \\
\hline $\begin{array}{l}\text { Ekonomske } \\
\text { mere }\end{array}$ & & $x$ & $x$ & $x$ & $x$ & $x$ & $x$ & $x$ \\
\hline $\begin{array}{l}\text { Medijska } \\
\text { propaganda }\end{array}$ & & $x$ & & $x$ & $x$ & $x$ & $x$ & $x$ \\
\hline $\begin{array}{l}\text { Obaveštajna } \\
\text { delatnost }\end{array}$ & & & & $x$ & & $x$ & & \\
\hline $\begin{array}{l}\text { Uticaj na socijalne } \\
\text { grupe }\end{array}$ & & $x$ & $x$ & $x$ & $x$ & $x$ & $x$ & \\
\hline Sajber napadi & $x$ & & & $x$ & & $x$ & $x$ & $x$ \\
\hline $\begin{array}{l}\text { Psihološke } \\
\text { operacije }\end{array}$ & $x$ & & & $x$ & $x$ & & $x$ & \\
\hline $\begin{array}{l}\text { Terorističke } \\
\text { aktivnosti }\end{array}$ & $x$ & $x$ & $x$ & $x$ & $x$ & $x$ & $x$ & \\
\hline $\begin{array}{l}\text { Kriminalne } \\
\text { aktivnosti }\end{array}$ & $x$ & $x$ & $x$ & $x$ & $x$ & $x$ & & \\
\hline $\begin{array}{l}\text { Pobune } \\
\text { stanovništva }\end{array}$ & $x$ & & $x$ & $x$ & & $\bar{x}$ & & $\bar{x}$ \\
\hline $\begin{array}{l}\text { Subverzivna } \\
\text { delatnost }\end{array}$ & & $x$ & & $x$ & $x$ & & & \\
\hline $\begin{array}{l}\text { Gerilska oružana } \\
\text { borba }\end{array}$ & & & & $x$ & $x$ & $x$ & & $x$ \\
\hline $\begin{array}{l}\text { Konvencionalne } \\
\text { vojne metode }\end{array}$ & $x$ & $x$ & & $x$ & & $x$ & $x$ & $x$ \\
\hline Pravne metode & & & & $x$ & & & & \\
\hline
\end{tabular}

${ }^{19}$ Glen R.W.: Thoughts on Hybrid Conflict, Small Wars Journal, 2009, str. 2; smallwarsjournal.com/ blog/journal/.

${ }^{20}$ Future Character of Conflict, HQ Land Forces, Ministarstvo odbrane V.B. London, 2010, str. 13.

${ }^{21}$ Lasconjairas G. i Larsen J.: Nato's response to hybrid threat, NATO Defense College, 2015; Erdal C., Murat A., Basar K.: Modeling and Simulation for Hybrid Environments, NMSG Conference, Bukurešt, 2016; Wales Summit Declaration, NATO, Vels, 2014; Peter P.: Deterring hybrid warfare: a chance for NATO and the EU to work together?, NATO Review, 18, Brisel, 2014.

${ }^{22}$ Křiž Z., Bechná Z., Števkov P.: Hybrid warfare: its concept, potential and how to fight it, članak u publikaciji Hybrid Warfare: A New Phenomenon in Europe's Security Environment, Jagello 2000, Prag, 2015; http://data.idnes.cz/soubory/na_knihovna/A161212_M02_029_HH16_PP-EN-V1.PDF.

${ }^{23}$ Koribko A.: Hybrid Wars: The Indirect Adaptive Approach To Regime Change, Narodni univerzitet Rusije, Moskva, 2015.

${ }^{24}$ Understanding Hybrid Warfare, MCDC /Multinational Capability Development Campaign project/, SAD, 2017; https://assets.publishing.service.gov.uk/government/uploads/system/uploads/attachment_data/file/647776/dar_ mcdc_hybrid_warfare.pdf.

${ }^{25}$ Munich Security Report 2015, Munich Security Conference, Minhen, 2015; https://www.security conference.de/fileadmin/MunichSecurityReport/MunichSecurityReport_2015.pdf. 
Stiče se utisak da iako ne postoji opšte prihvaćena definicija, različiti autori se u većem delu slažu o sadržaju hibridnog rata. U tabeli nije prikazan deo mišljenja koja su iznošena načelno u periodu od 2006. do 2014. godine, a koja se u manjoj ili većoj meri poklapaju sa stavovima Frenka Hofmana, i koje su ograničene na neposredno ugrožavanje vojnih snaga na terenu od strane nedržavnih aktera, dakle na taktički i operativni nivo vojnih operacija. Opredeljenje je da se težišno prikaže šire i prisutnije tumačenje termina hibridni rat, koje uključuje sve one sadržaje koje jedna država (a ne samo nedržavni akteri) mogu da preduzmu. Zaključuje se da se kao najznačajniji sadržaj hibridnog ratovanja mogu uzeti sledeći oblici delovanja na protivnika u cilju primoravanja na ispunjenje zahteva:

- Informaciono-psihološko-ideološko delovanje

- Političko delovanje

- Ekonomski pritisci

- Obaveštajno-subverzivna delatnost

- Informatičke metode

- Kriminalne aktivnosti

- Terorizam i oružane pobune

- Konvencionalno vojno delovanje

Pod-sadržaji navedenih oblika bi mogli da budu razne druge radnje nižeg nivoa ugrožavanja, aktivnosti na operativnom i taktičkom nivou kao što su: uticaj na političko rukovodstvo, psihološke operacije, korupcija, atentati, medijska propaganda i spinovanje, osnivanje nevladinih organizacija pod kontrolom stranog faktora, uticaj na određene socijalne grupe, finansiranje određenih političkih stranaka, ucene, vrbovanje državnih službenika od strane obaveštajnih službi, izazivanje podela, nezadovoljstva, jačanje razlika, izazivanje građanskih nemira, pojedinačni teroristički akti, napadi oružanih grupa na određene kritične objekte, linije komunikacija i logistike, dezinformisanje stanovništva itd. Operacionalizacija određenih metoda, njihove implikacije i posledice nisu dalje vršene. Moguće je vršiti i uopštavanje pa bi se neki od navedenih sadržaja kao što su informatički napadi, terorizam, kriminalne aktivnosti, mogle pripisati recimo ofanzivnom radu obaveštajno-bezbednosnih službi, kao jednog od glavnih nosioca nekonvencionalnog ratovanja, agresije koja treba da bude nevidljiva, neprimetna a u isto vreme da ostvaruje svoj efekat. Sinteza je ipak izvršena na jednom dovoljno uopštenom nivou koji obuhvata ključna polja delovanja a radi realnog prikaza pojave.

Teorija ratne veštine je bogata mišljenjima o ratu, sukobima, pa se postavlja pitanje odnosa aktuelnog hibridnog rata sa dosadašnjom teorijom i praksom. Nauka prepoznaje dve različite grupe teorija o ratu: klasične (modernističke) i savremene (postmodernističke). ${ }^{26}$ Teorije „klasičnog rata“ suštinu rata vide u primeni sile, fizičkog nasilja, sa dominantnim oružanim sukobom u okviru sadržaja, sa bojnim poljem kao mestom gde se vodi rat, kao sukob koji ima svoj početak i kraj i koji se ispoljava pre svega kroz fizičke posledice. $^{27}$ Savremene teorije o ratu govore o ratu kao o višedimenzionalnom sukobu, a koji se ispoljava u verbalnim sredstvima (politici, diplomatiji, ekonomiji, veri, moralu, kulturi) i

\footnotetext{
${ }^{26}$ Kovač M., Forca B.: Istorija ratne veštine - period 1920 - 2000, Vojnoizdavački zavod, Beograd, 2000, str. 315.

${ }^{27} \mathrm{U}$ ovu grupu se ubrajaju antropološko-kultorološka, bilogistička, psihologistička, etička, geopolitička, ekonomistička, demografska i druge teorije. Isto, str. 315.
} 
fizičkim (nasilje, oružana borba, uništenje ljudi i dobara) ${ }^{28}$ Suština savremenih teorija je da rat nije samo oružani sukob nego i sukob različitih interesa u okviru koga se primenjuju sve raspoložive mere koje strane poseduju kako bi potčinile svojoj volji drugu stranu. Uklapa se u poimanje hibridnog rata, zar ne?

Kao posebno slični termini i pojmovi današnjem hibridnom ratu, do 1990. godine su se pominjali totalni, hladni, specijalni rat, sukob niskog intenziteta, a od 1990. i rat 4. generacije, neograničeno ratovanje, složeni, asimetrični, neregularni rat. Totalni rat predstavlja vrstu rata u kojem ratujuće strane koriste sve raspoložive ljudske, materijalne i tehničke potencijale radi ostvarivanja svojih ciljeva. ${ }^{29} \mathrm{U}$ američkoj leksikografiji je definisan kao sukob u kojem su angažovani politički, ekonomski, vojni i psihološki resursi od strane barem jednog učesnika u sukobu. ${ }^{30}$ Hladni rat se kao termin pojavio u literaturi bez posebnog definisanja samog pojma. U zvaničnoj publikaciji Združenog generalštaba oružanih snaga $S A D^{31}$ izneto je da je hladni rat stanje međunarodne zategnutosti u kojem se koriste politička, ekonomska, tehnološka, sociološka, psihološka, paravojna i vojna sredstva bez neposrednog angažovanja operativnih jedinica regularne vojske, radi postizanja vitalnih nacionalnih ciljeva. Specijalni rat (special warfare) se kao termin pojavio u doba Hladnog rata, sredinom 60 -ih godina prošlog veka, najpre u SAD kako bi objasnio delovanje u Vijetnamu. Termin je prihvaćen i u našoj literaturi, koja je nastajala nakon II svetskog rata. Specijalni rat je definisan kao kompleks organizovanih aktivnosti, mera i dejstava na ideološkom, političkom, ekonomskom, kulturnom, diplomatskom, psihološko-propagandnom, obaveštajnom i vojnom planu koji se u miru preduzimaju protiv neke zemlje. ${ }^{32}$ Neograničeno ratovanje je termin koji se pojavio u Kini 1999. godine, kada je objavljena knjiga Unrestricted warfare, u kojoj se razmatraju mogućnosti Kine u ratu protiv SAD, u slučaju kada su oni inferiorniji u pogledu klasične vojne moći, ali nisu u pogledu primene mnogih drugih oblika ratovanja kojima bi mogli da nanesu štetu SAD, kao što su sajber ratovanje, terorizam, targetiranje finansijskih institucija, rat kursom nacionalnih valuta, medijski rat, urbano ratovanje, itd. ${ }^{33}$

Sadržaj hibridnog rata dakle nije ništa novo i nepoznato za teoriju ratne veštine. Prema definicijama različitih autora sigurno je da se može svrstati u grupu savremenih poimanja ratova, u kojima se sve više daje značaj neoružanim oblicima ratovanja. Rat u klasičnom smislu te reči, kao veći oružani sukob, je uvek bio i najskuplji način ostvarivanja geopolitičkih i ekonomskih interesa (i u materijalnom smislu i u smislu žrtava), pa je primena drugih metoda za ostvarivanje tih interesa dobijala više na značaju tokom vremena. Kao zajedničko većini navedenih vrsta ratova sa hibridnim ratom, može se navesti pre svega sveobuhvatnost, svedimenzionalnost ili totalitet - ispoljavanje u skoro svim dimenzijama nacionalne moći, osim nuklearne (kod zemalja koje je poseduju), čija primena

\footnotetext{
${ }^{28} \mathrm{U}$ ovu grupu terija se ubrajaju između ostalih i globalistička teorija, vojnoelitistička, psihološko-informaciona i informatičko-teološka. Isto.

${ }^{29}$ Mikić S.B.: Pogled na rat, Vojna akademija, Vojnoizdavački zavod, Beograd, 2003.

${ }^{30}$ Mirković T: Strategije i ratne doktrine supersila i blokova, Vojnoizdavački zavod, Beograd, 2003.

${ }^{31}$ JCS Publication, Ministarstvo odbrane SAD, Vašington, januar, 1972.

${ }^{32}$ Vilić D., Ateljević M.: Specijalni rat - odbrana i zaštita, Poslovna politika, Beograd, 1986, 20.

${ }^{33}$ Qiao L. i Wang X.: Unrestricted Warfare: China's Master Plan to Destroy America, Pan American Publishing Company, Los Anđeles, 2002, 1999. u Kini; http://www.c4i.org/unrestricted.pdf.
} 
bi sigurno značila i drugačiju karakterizaciju rata. Ovo se odnosi i na one strane u sukobu koje su slabije, inferiornije, jer u suštini i one koriste u ovakvim sukobima sve što im je na raspolaganju (medije, diplomatiju, obaveštajne službe, ekonomske mere itd.), samo sa uspehom srazmernim njihovoj moći. Sigurno je i da se zavisno od protivnika, mogućnosti i ciljeva, razlikuje obim i način primene, intenzitet i vreme ispoljavanja pojedinih metoda ratovanja ili agresije, a što se može videti iz sledeće tabele koju su Mitar Kovač i Božidar Forca objavili 2000. godine, govoreći o totalitarnosti savremenih ratova, njihovom, obimu i intenzitetu:

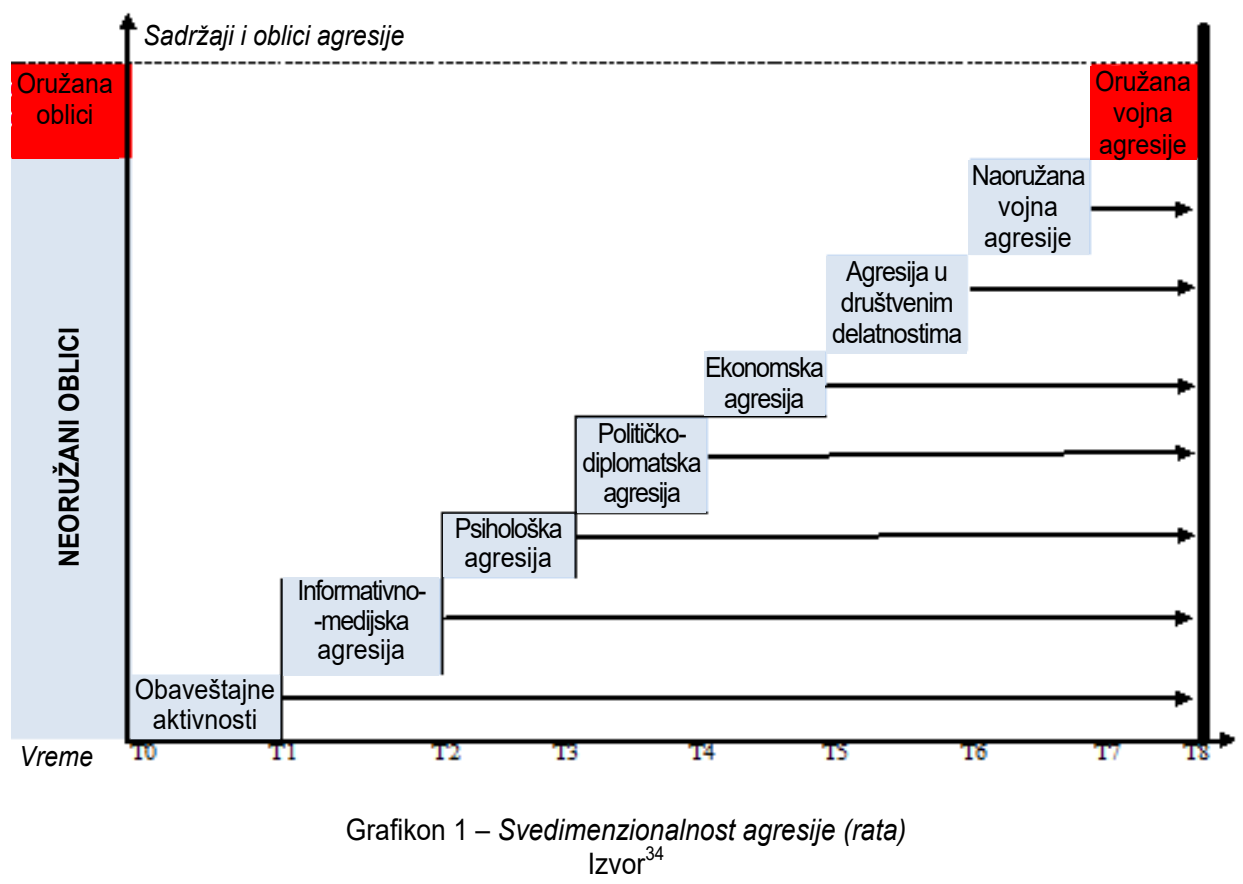

\section{Pojam hibridni rat}

Definisanje pojma hibridni rat zahteva najpre semantičku analizu značenja sintagme. Reč hibrid potiče od latinske reči hybrida koja je označavala životinju ili biljku dobijenu ukrštanjem dve različite vrste. $U$ većini današnjih jezika reč se koristi kako bi označila mešavinu ili kombinaciju. Reč hibridni kao pridev se koristi da označi da je određen objekat ili proces nastao kao rezultat spajanja dva ili više različita objekta ili procesa. Posebnost se sastoji u tome da elementi koji se spajaju već predstavljaju, sami za sebe, odre-

\footnotetext{
${ }^{34}$ Kovač M., Forca B.: Istorija ratne veštine - period 1920 - 2000, Vojnoizdavački zavod, Beograd, 2000, str. 361.
} 
đenu podcelinu a spajanjem sa drugim elementima se dobijaju nove poželjne osobine. Hibridan znači da se za istu funkciju koriste dva ili više rešenja od kojih svako ima svoj specifičan unutrašnji sadržaj. ${ }^{35}$

Reč rat u Rečniku srpskog jezika ima dva značenja: 1) oružani sukob širih razmera između dveju ili više država; 2) figurativno značenje kao oštri međusobni sukobi zavađenih strana svim sredstvima osim oružanim (sa komšijama, između preduzeća). Zatim se daje i objašnjenje za sintagmu građanski rat - oružani sukob u okviru jedne države između zaraćenih entiteta i hladni rat - stanje zategnutosti i neprijateljstva u međunarodnim odnosima. ${ }^{36} \mathrm{U}$ monografiji Srpska vojna leksika i terminologija se navodi da je termin rat, pored osnovnog značenja „oružani sukob između protivnika“, razvio i metaforično značenje kao „žestoki međusobni napadi zavađenih strana svim sredstvima osim oružja“, te se njime može objašnjavati i sukob dva lica, različitih mišljenja itd. Reč rat pripada opšteknjiževnom, neutralnom leksičkom fondu a dopunski kvalitet je njegova terminološka funkcija jer je tokom jezičke evolucije razvio i druga, prenesena značenja koja se mogu sagledati u okviru zajedničke pojmovne percepcije. ${ }^{37}$ Engleska reč war (u prevodu rat), ima sledeća semantička značenja: oružani konflikt između različitih država ili grupa u okviru države; period oružanog neprijateljstva ili sprovođenja vojnih operacija; oružana borba kao profesija, aktivnost; agresivni poslovni konflikt (,rat između avio prevoznika“, „trgovački rat"); suprotstavljenost i neprijateljstva između različitih ljudi ili grupa; kampanja protiv nepoželjne aktivnosti („država vodi rat protiv krijumčara"); nastojanje da se postigne cilj („rat protiv raka“, „rat protiv siromaštva“).

Upotreba termina rat van ratne vojne veštine je bila predmet raznih diskusija. Njegovo značenje je ipak dobilo široku upotrebu i van osnovnog značenja kao oružane borbe između vojski država ili većih entiteta. Tako se danas susrećemo sa pojmovima koji označavaju i druge dimenzije sukoba kao što su medijski rat, ekonomski rat, carinski rat, sajber rat, psihološki rat, rad obaveštajnih službi, elektronski rat, diplomatski rat, neograničeni rat itd. U skladu sa navedenim se može zaključiti da je sintagma hibridni rat nastala tako što je termin hibridni preuzeta iz drugih naučnih disciplina i iskorišćena u sintagmi kako bi označila jedinstven konflikt, stanje sukobljenosti, neprijateljstvo, proces, koji se ispoljava kroz primenu sile u različitim društvenim poljima.

Radi definisanja pojma hibridni rat analiziraćemo i dosadašnje definicije koje su određeni autori iznosili. Donekle otežavajuću okolnost predstavlja činjenica da su pojedini autori ili organizacije iznosile ocenu šta su to hibridne pretnje, bez upuštanja u definisanje pojma rat. Pregled definicija prilažemo u sledećoj tabeli:

\footnotetext{
${ }^{35}$ U kartografiji se izrazom „hibridni prikaz“ označava naziv snimka iz vazduha u koji su naknadno uneti nazivi ulica i objekata. U hemiji i atomskoj fizici se linearne kombinacije orbitala nazivaju „hibridne orbitale“. U golfu „hibrid“ je štap koji pokušava objediniti dužinu udarca drvenog štapa sa lakim rukovanjem metalnim štapom. U tenisu „hibrid“ je reket koji ima uzdužne žice izrađene od drugačijeg materijala nego poprečne žice. U lingvistici se „hibridom“ označava reč sastavljena od reči iz različitih jezika. U tehnici se „hibridom“ označava sistem kod koga se kombinuju dve ili više različitih tehnologija („hibridni automobil“ ima dva ili više izvora napajanja). U botanici, genetici i zoologiji se „hibridom“ označava seme ili živo biće koje nastalo ukrštanjem semena ili roditelja različitih uzgojnih linija, pasmina ili vrsta (www.merriam-webster.com/dictionary/hybrid).

${ }^{36}$ Rečnik srpskog jezika, Matica srpska, Novi Sad, 2011.

${ }^{37}$ Jovanović V.: Srpska vojna leksika i terminologija, Institut za srpski jezik SANU, Beograd, 2016.

${ }^{38}$ Internet: http://www.dictionary.com/browse/war?s=t.
} 
Tabela 2 - Pregled definicija hibridnog rata u literaturi

\begin{tabular}{|c|c|}
\hline Izvor & Definicija/mišljenje \\
\hline $\begin{array}{l}\text { Frank } \\
\text { Hoffman }^{39} \\
\text { SAD, } 2007\end{array}$ & $\begin{array}{l}\text { Hibridnu pretnju predstavlja bilo koji protivnik koji istovremeno i adaptivno } \\
\text { upotrebljava konvencionalno oružje, neregularne taktike, terorizam i kriminalne } \\
\text { aktivnosti u borbenom prostoru kako bi ostvarili svoje političke ciljeve. }\end{array}$ \\
\hline $\begin{array}{l}\text { John McCuen } \\
\text { SAD, } 2008 .\end{array}$ & $\begin{array}{l}\text { Hibridni ratovi su kombi120 } \\
\text { nacija simetričnog i asimetričnog rata u kojem interventne snage sprovode } \\
\text { tradicionalne vojne operacije protiv neprijateljskih vojnih snaga dok moraju } \\
\text { istovremeno i još odlučnije da uspostavljaju kontrolu autohtonog stanovništva u } \\
\text { zoni operacije obezbeđujući i stabilizujući ih. }\end{array}$ \\
\hline $\begin{array}{l}\text { Russell W. } \\
\text { Glenn }^{41} \\
\text { SAD, } 2009\end{array}$ & $\begin{array}{l}\text { Hibridne pretnje predstavljaju kombinaciju istovremeno primenjenih (1) političkih, } \\
\text { vojnih, ekonomskih, društvenih i informativnih sredstava i (2) konvencionalnih, } \\
\text { neregularnih, katastrofičnih, terorističkih } i \text { kriminalnih sredstava ili aktivnosti u } \\
\text { operativnom borbenom prostoru. Umesto jednog entiteta, hibridna pretnja ili } \\
\text { izazivač može biti kombinacija državnih i nedržavnih aktera. }\end{array}$ \\
\hline $\begin{array}{l}\text { "U.S Army Field } \\
\text { Manual 5-0“42 } \\
\text { SAD, } 2011\end{array}$ & $\begin{array}{l}\text { Hibridne pretnje predstavljaju dinamičku kombinaciju konvencionalnih, } \\
\text { neregularnih, terorističkih i kriminalnih resursa, prilagođenih da se suprotstave } \\
\text { tradicionalnim prednostima koje ima američka vojska. Ove pretnje su sjedinjene } \\
\text { da postignu zajednički efekat. Ove pretnje koriste medije, informatičke i druge } \\
\text { nove tehnologije, svoje pozicije unutar policije, vojske ili socijalnih struktura, da } \\
\text { ostvare prednost. }\end{array}$ \\
\hline $\begin{array}{l}\text { Timothy C. } \\
\text { Richard J. } \\
\text { SAD, } 2013\end{array}$ & $\begin{array}{l}\text { Hibridni rat je nasilan konflikt u kome se od strane regularnih i neregularnih } \\
\text { snaga, sprovodi kompleksna i organizovana upotreba sredstava i aktivnosti u više } \\
\text { domena kako bi se postigao sinergijski efekat koji pokušava da iscrpi superiornu } \\
\text { vojnu silu. }\end{array}$ \\
\hline $\begin{array}{l}\text { Robert } \\
\text { Newson } \\
\text { SAD, } 2014 \text {. }\end{array}$ & $\begin{array}{l}\text { Hibridni rat je kombinacija konvencionalnih, neregularnih i asimetričnih metoda, } \\
\text { koja podrazumeva kontinuiranu manipulaciju političkim i ideološkim konfliktom, } \\
\text { kao i angažovanje specijalnih oružanih snaga, konvencionalnih trupa, } \\
\text { obaveštajnih agenata, političkih provokatora, predstavnika medija, ekonomske } \\
\text { ucene, sajber napade, para-vojne, terorističke i kriminalne elemente. }\end{array}$ \\
\hline
\end{tabular}

${ }^{39}$ Hoffman F.: Conflict in the 21st Century: the Rise of Hybrid Wars. Potomac Institute for Policy Studies, Arlington, Virginia, 2007; www.potomacinstitute.org/images/stories/publications/potomac_hybridwar_0108.pdf

40 MecCuen J.: Hybrid Wars, Military Review, 2008; http://ww.au.afmil/au/awc/awcgate/milreview/ mccuen08marapr.pdf.

${ }^{41}$ Glen R.W.: Thoughts on Hybrid Conflict, Small Wars Journal, 2009, str. 2; www.smallwarsjournal. com/blog/journal/.

${ }^{42}$ Field Manual 5-0: The Operations Process, Headquarters, Department of the Army, Washington, 2011.

${ }^{43}$ McCulloh T., Johnson R.: The Nature of Hybrid Warfare: Built to Last, Joint Special Operations University Report, 2013; http://www.socom.mil/JSOU/JSOUPublications/JSOU\%2013-4_McCulloh,Johnson_Hybrid\%20 Warfare_final.pdf. 


\begin{tabular}{|c|c|}
\hline Izvor & Definicija/mišljenje \\
\hline $\begin{array}{l}\text { Peter Pindják }{ }^{45} \\
\text { Brisel, } 2014\end{array}$ & $\begin{array}{l}\text { "Hibridni rat obuhvata niz nekonvencionalnih napora dizajniranih da destabilizuju } \\
\text { državu i podstiču unutrašnje sukobe. Sastoji se od kombinacije vojnih i ne-vojnih } \\
\text { sredstava u okviru otvorenih i prikrivenih operacija, propagande, stvaranja } \\
\text { nevladinih organizacija (NVO), ometanje administracija, javnog života, podsticanja } \\
\text { neslaganja, sve do isporuka oružja i direktne upotrebe sile. Za razliku od } \\
\text { konvencionalnog ratovanja, koji cilja na oružane snage „centar gravitacije“ u } \\
\text { hibridnom ratu je stanovništvo. Protivnik pokušava da utiče na ključne donosioce } \\
\text { odluka ... Agresor se usmerava na tajne akcije kako bi izbegao pripisivanje ili } \\
\text { odmazdu". }\end{array}$ \\
\hline $\begin{array}{l}\text { Zdeněk K. } \\
\text { Zinaida B. } \\
\text { Peter Š. }{ }^{46} \\
\text { Češka, } 2015 .\end{array}$ & $\begin{array}{l}\text { Hibridni rat je oružani sukob sproveden kombinacijom ne-vojnih i vojnih sredstava } \\
\text { kako bi se sinergijskim efektom prisilio neprijatelja da preduzme korake koje ne bi } \\
\text { inače uradio. Najmanje jedna strana u sukobu je država. Glavnu ulogu ima } \\
\text { primena ne-vojnih metoda kao što su psihološke operacije i propaganda, } \\
\text { ekonomske sankcije, embargo, kriminalne aktivnosti, terorističke aktivnosti i druge } \\
\text { subverzivne aktivnosti... a koje se sprovode protiv celog društva, a posebno protiv } \\
\text { političkih struktura, državnih organa, ekonomije, morala naroda i oružanih snaga. }\end{array}$ \\
\hline $\begin{array}{l}\text { Andrej } \\
\text { Koribko }^{47} \\
\text { Moskva, } 2015\end{array}$ & $\begin{array}{l}\text { Elementi hibridnog rata su: diplomatija, informatički napadi, ekonomski rat, } \\
\text { informativni rat i propaganda, podrška lokalnim grupama, neregularne oružane } \\
\text { snage (terorizam), regularne oružane snage i specijalne jedinice. Hibridni rat } \\
\text { definiše kao kombinaciju svih ovih elemenata koje se primenjuju od strane } \\
\text { jedne ili više država prema objektu ugrožavanja, najčešće drugoj državi. }\end{array}$ \\
\hline 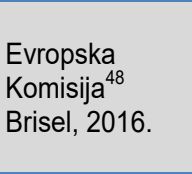 & $\begin{array}{l}\text {.... koncept EU ima za cilj da obuhvati kombinovane prisilne i subverzivne } \\
\text { aktivnosti, konvencionalne i nekonvencionalne metode (npr. diplomatske, } \\
\text { vojne, ekonomske, tehnološke, informacione), koje se koriste na koordinisan } \\
\text { način od strane državnih ili nedržavnih aktera kako bi postigli konkretne ciljeve } \\
\text { bez proglašenog rata. }\end{array}$ \\
\hline $\begin{array}{l}\text { Grupa autora } \\
\text { Ukrajina, } 2017 .\end{array}$ & $\begin{array}{l}\text { Hibridni ratovi su simbioza uništavanja vojnog i političkog sistema protivnika } \\
\text { ucenjivanjem, podmićivanjem, subverzijama, klevetama, informativnim pritiscima i } \\
\text { manipulacijama javne svesti. Kombinacija vojnih i ne-vojnih tehnika korišćenjem } \\
\text { potencijala društvenog protesta je srž ratova nove generacije. }{ }^{49}\end{array}$ \\
\hline
\end{tabular}

${ }^{44}$ Mueller R.: Why the US Needs a Strategy To Counter 'Hybrid Warfare, The U.S. Army Special Operations Command (USASOC), 2014; https://www.defenseone.com/ideas/2014/10/why-us-needs-strategy-counter-hybrid- warfare/97259/.

${ }^{45}$ Pindjak P.: Deterring hybrid warfare: a chance for NATO and the EU to work together?, NATO Review, 18, Brisel, 2014; https://www.nato.int/docu/review/2014/Also-in-2014/Deterring-hybrid-warfare/EN/ index.htm.

${ }^{46}$ Křiž Z., Bechná Z., Števkov P.: Hybrid warfare: its concept, potential and how to fight it, članak u publikaciji Hybrid Warfare: A New Phenomenon in Europe's Security Environment, Jagello 2000, Prag, 2015; http://data.idnes.cz/soubory/na_knihovna/A161212_M02_029_HH16_PP-EN-V1.PDF.

${ }^{47}$ Koribko A.: Hybrid Wars: The Indirect Adaptive Approach To Regime Change, Narodni univerzitet Rusije, Moskva, 2015; https://orientalreview.org/wp-content/uploads/2015/08/AK-Hybrid-Wars-updated.pdf.

${ }^{48}$ European Commission, Joint Framework on countering hybrid threats a European Union response, Brisel, 2016; https://eur-lex.europa.eu/legal-content/EN/TXT/?uri=CELEX:52016JC0018.

${ }^{49}$ Dodonov R., Kovalskyi H., Dodonova V., Maryna K.: Polemological Paradigm of Hybrid War Research, Philosophy and Cosmology, 19, Kijev, Ukrajina, 2017, str. 2; http://ispcjournal.org/journals/2017-19/Dodonov KovalskyiKolinko_19.pdf. 
Operacionalizaciju navedenih a i nekih drugih poimanja hibridnog rata, možemo izvršiti kroz ustanovljavanje odgovora na jednostavna pitanja - šta je to hibridni rat, ko ga vodi, kako se vodi, gde se vodi, na koga je usmeren, i zašto se vodi (tabela 3 )?

Tabela 3 - Operacionalizacija definicija hibridnog rata

\begin{tabular}{|c|c|}
\hline Šta? & $\begin{array}{l}\text { oružani sukob, nasilan konflikt, niz napora, simbioza uništavanja sistema protivnika, } \\
\text { suberzivna aktivnost, kombinacija resursa, kombinacija metoda }\end{array}$ \\
\hline Ko? & $\begin{array}{l}\text { jedna ili više država, državni, nedržavni akteri, kombinacija državnih i nedržavnih } \\
\text { aktera, protivnik, regularne snage, neregularne snage }\end{array}$ \\
\hline Kako? & $\begin{array}{l}\text { upotreba konvencionalnog oružja, neregularne taktike, terorizma, kriminalnih, } \\
\text { subverzivnih aktivnosti; konvencionalne i nekonvencionalne metode; diplomatske, } \\
\text { ekonomske, političke, informativne, propagandne, obaveštajne metode, informatički } \\
\text { napadi; ucenjivanjem, podmićivanjem, klevetama, manipulacijama javne svesti, } \\
\text { društvenim protestima; stvaranje nevladinih organizacija, ometanje administracija, } \\
\text { javnog života, podsticanje neslaganja; podrška lokalnim grupama, korišćenje } \\
\text { specijalnih jedinica, prikrivene operacije, isporuke oružja; upotreba konvencionalnih } \\
\text { trupa, obaveštajnih agenata, političkih provokatora, predstavnika medija, para- } \\
\text { vojnih, terorističkih i kriminalnih elemenata; ekonomske ucene, korišćenje pozicija } \\
\text { unutar policije, vojske ili socijalnih struktura. }\end{array}$ \\
\hline Gde? & $\begin{array}{l}\text { borbeni prostor, zona operacije, na celoj ili delu teritorije protivnika, u svim oblastima } \\
\text { društvenog delovanja (ekonomiji, politici, medijima, sajber prostoru, socijalnim } \\
\text { odnosima, kulturi, sportu) }\end{array}$ \\
\hline Prema? & $\begin{array}{l}\text { društvu, državi, savezu država, političkoj zajednici, stanovništvu, oružanim } \\
\text { snagama, ekonomskim resursima, privrednim društvima, političkim vlastima, lokalnoj } \\
\text { samoupravi, državnim službenicima (posebno u vojsci, policiji, bezbednosnim } \\
\text { službama), političkim strankama, kulturnim, ideološkim i moralnim vrednostima, } \\
\text { socijalnim, političkim i drugim društvenim odnosima, značajnim pojedincima, } \\
\text { međunarodnim ili domaćim organizacijama. }\end{array}$ \\
\hline Zašto ? & $\begin{array}{l}\text { ostvarivanja konkretnih interesa i ciljeva, pokoravanja subjekta ugrožavanja, } \\
\text { prisiljavanja neprijatelja da preduzme takve korake koje on ne bi uradio sam po sebi, } \\
\text { radi uticaja na ključne donosioce odluka, iscrpljivanje protivnika, ostvarivanje } \\
\text { političkih ciljeva. }\end{array}$ \\
\hline
\end{tabular}

Iz navedenog se može uočiti raznovrsnost termina koji su korišćeni za definisanje hibridnog rata, često bez korišćenja naučnih pojmova, jasne karakterizacije pojave, njenih uzroka, osnovnih karakteristika, ciljeva zbog kojih se hibridni rat vodi, i slično. Mali broj autora je za definisanje koristio termin sukob te umesto toga upotrebljavao termine poput aktivnosti, napori, kombinacija metoda i sl. Može se uočiti da se hibridni rat uglavnom smatra procesom, skupom aktivnosti. Kod određenih autora postoji i neodređenost po pitanju učesnika hibridnog rata, ili nosilaca hibridne agresije, pa su korišćeni termini poput „državni i nedržavni akteri“, „regularne i neregularne snage“. Klasifikacija metoda ugrožavanja je različita od autora do autora, često uz korišćenje pojedinačnih a zanemarivanje opštijih pojmova koji se odnose na određenu oblast delovanja. Ipak se može uočiti glavna ideja koja prati pojam hibridnog rata, a to je korišćenje čitavog niza neoružanih oblika delovanja od strane učesnika rata, pri čemu se oni uglavnom kombinuju i sa oružanim.

Jedan od razloga nepostojanja opšteprihvaćene definicije hibridnog rata je i činjenica da postoje različita mišljenja o samoj vrsti, karakteru i prostoru rata - da li je to rat koji se 
vodi u ograničenom borbenom prostoru (kako su ga uglavnom videli američki autori opisivanjem ratova u Iraku, Avganistanu) ili je to rat države protiv države, kako se na to gledalo kasnije, posebno posle 2014. godine i krize u Ukrajini, a uglavnom i danas.

Metodologija nas uči da pojam predstavlja misaoni odraz osobina i odnosa jedne pojave ili predmeta. Svaki pojam ima određene karakteristike, elemente. Govorni izraz pojma je termin. Pojam treba da bude stabilan a termin može da bude promenljiv. U teoriji a i praktično često dolazi do izražavanja istog pojma različitim terminima. I pojmovi i termini mogu vremenom da se menjaju, zavisno od novih saznanja suštine neke pojave ili predmeta. ${ }^{50}$ Svi pojmovi zahtevaju definisanje, radi jasnoće, lakše klasifikacije, a kako ne bi dolazilo do sukoba mišljenja. Davanjem odgovora na pitanja kojima smo operacionalizovali definicije hibridnog rata (šta, ko, kako, protiv koga, gde, zašto), potrebno je definisati i pojam hibridnog rata.

Ranije smo već zaključili, da hibridni rat predstavlja vrstu sukoba, koja se ispoljava kroz kombinaciju neoružanih i oružanih oblika delovanja, sa težišnim učešćem ovih prvih. Pri tome se može diskutovati i to da li je hibridni rat - rat, ili agresija, s obzirom da je dobar broj autora svoje definicije formulisao težišno opisujući delovanje jedne strane (ISIL u Iraku, Rusije u Ukrajini, SAD u Libiji i Siriji). Da li je rat hibridni ako samo jedna strana primenjuje hibridne pretnje i oblike delovanja, a druga samo trpi ili pokušava da se odbrani, ne primenjujući i nemajući moći da primeni recipročne odgovore? U Vojnom leksikonu je data definicija agresije: „Agresija je neizazvani napad jedne ili više država na drugu, kojim se ugrožavaju nezavisnost, suverenitet ili teritorijalna celina zemlje. Najčešće je agresija oružana, odnosno izvodi se primenom vojne sile, ali obuhvata svaku akciju usmerenu protiv teritorijalne celine ili nezavisnosti druge države, ili protiv mira u svetu. $U$ tom smislu se govori o ekonomskoj, političkoj, subverzivnoj i drugim vrstama agresije, a često i o tzv. ideološkoj agresiji“. ${ }^{51}$ Agresija u međunarodnom pravu predstavlja akt upotrebe sile, odnosno napad koji jedna država izvrši protiv druge države, ili drugih pravno zaštićenih objekata. Agresija je zločin. Povelja OUN (član 2., tačka 4.) zabranjuje ne samo oružani napad već svaku upotrebu sile protiv neke države. ${ }^{52}$ Pravni okvir i terminologija dakle možda postoje za veći deo onoga što se danas smatra hibridnim ratom - primena sile (ne samo oružane) jedne ili više država protiv druge. Međutim takav diskurs, raspravu o hibridnom ratovanju verovatno bi odveo u nepoželjnom smeru za određene zemlje, jer bi se postavilo pitanje kršenja međunarodnog prava u određenim slučajevima. Ukoliko se hibridni rat svodi na napade samo jedne strane u sukobu, hibridna agresija bi možda bio ispravniji termin. Međutim, s obzirom da je u pitanju pre svega sukob, to podrazumeva da i druga, napadnuta strana, primenjuje određene mere radi svoje zaštite, odbrane pa i napada na agresora, ne morajući obavezno da one budu okarakterisane kao hibridne, da bi ceo sukob bio okarakterisan kao hibridni.

Praksa je pokazala i da je barem jedna država učesnik hibridnog rata. Država, kao najviši i najsavršeniji oblik političkog i društvenog organizovanja jednog naroda ili stanovništva različitih nacija na jednoj teritoriji, je bila i ostala osnovni pokretač društvenih odnosa, posebno u međunarodnim okvirima. Istorija je takođe pokazala da su ratovi uglavnom bili inicirani od strane jedne ili više država. I većina unutrašnjih neoružanih sukoba, zaoštravanje

\footnotetext{
${ }^{50}$ Marković M.: Logika, Zavod za udžbenike i nastavna sredstva, Beograd, 1994.

${ }^{51}$ Vojnik leksikon, VIZ, Beograd, 1981.

${ }^{52}$ Politička enciklopedija, Savremena administracija, Beograd, 1975.
} 
međunacinalnih odnosa, politička i socijalna previranja, su takođe bila podržavana pa i od početka inicirana spolja, od strane stranih zemalja ili interesnih grupa u njima. Pri tome, ne mora po pravilu da oba učesnika hibridnog rata budu države. Kao jedna od strana u sukobu može da se javi i određena društvena grupa, pokret, politička, etnička, nacionalna, interesna pa i teroristička organizacija. Moglo bi se reći da takve organizacije uvek imaju određene političke ciljeve, suprotne interese u odnosu na neku državu ili njenu vlast. Kao primere organizacija, a koje su prema teoretičarima, pre svega iz SAD, zapadne Evrope i lzraela, vodili hibridne ratove ili bar okarakterisani kao nosioci hibridnih pretnji, možemo uzeti ISIL u Iraku i Siriji, talibane u Avganistanu ili Hezbolah u Libanu. ${ }^{53}$

Kod analize sadržaja hibridnog rata, može se uočiti zakonitost da se hibridni rat ispoljava kroz primenu različitih nevojnih i vojnih oblika ugrožavanja. Oblici delovanja u hibridnom ratu se mogu grupisati u sledeće pojmove: informaciono-psihološko-ideološko delovanje, političko delovanje, ekonomski pritisci, obaveštajno-subverzivna delatnost, informatičke metode, kriminalne aktivnosti, terorizam i oružane pobune i konvencionalno vojno delovanje.

Treba razlikovati oblike delovanja od oblasti delovanja ili prostora u kome se ti oblici ispoljavaju. Priroda i karakter hibridnog rata upućuju na totalitet, višedimenzionalnost, globalnost kao karakteristike, u smislu da se rat vodi u prostoru celokupnog društvenog života protivnika bilo da je u pitanju agresija na državu, nacionalnu, političku zajednicu ili organizaciju. To mogu biti: oblast političkih odnosa, ekonomija, oblast informacija i komunikacija, oblast bezbednosti (vojska, policija, bezbednosne službe), oblast socijalnih odnosa, demografije, vere, prava, nauke i tehnologije, istorije, obrazovanja, kulture, sporta, zdravstva, ekologije, morala, ideologije, nacionalnih vrednosti i interesa. Pri tome treba uzeti u obzir i da se rat može voditi na delu ili celoj teritoriji države, nacionalne ili političke zajednice, prostoru gde se nalaze određene oružane snage, ali takođe $i$ u svetu, tamo gde određena zemlja ili grupa imaju svoje interese, bez obzira da li je to prijateljstvo sa nekom zemljom ili rešavanje njenih interesa u međunarodnim organizacijama kakve su UN ili finansijske institucije.

Objekti ugrožavanja u hibridnom ratu mogu biti pojedinci, grupe ljudi, svo stanovništvo na određenoj teritoriji ili njenom delu, društva, države ili savezi država. Treba razlikovati mentalnu i fizičku sferu uticaja, pri čemu se pod mentalnom sferom smatraju različiti društveni odnosi, znanja, moralne i kulturne norme, vrednosti i interesi a pod fizičkom sva materijalna dobra i predmeti koje objekat ugrožavanja poseduje.

Uzroci hibridnog rata bi mogli da se objasne različitim interesima i ciljevima strane koja ga izaziva i vodi. Teorija ratne veštine je imala različita objašnjenja. Od toga da je rat pokretač progresa a da mir usporava društveni razvoj (etička teorija), preko toga da je u prirodi čoveka da ratuje i da je on njegov osnovni uzrok (biologistička teorija), da je rat uzrokovan rasnom nejednakošću među ljudima (rasna teorija), da je suverenitet naroda uzrok ratova i da ga je nemoguće izbeći dok postoje države i nacije (kosmopolitska), do objašnjenja da je rat uzrokovan potrebom za proširenjem životnog prostora, težnjom za dominacijom nad drugim narodima i državama (geopolitička teorija). Uzroci se svode na različite interese koji proizilaze iz moći pojedinih država, koje tu moć koriste za održavanje i dalje jačanje. U suštini mogu da se svedu pre svega na ekonomske, a posredno i političke i vojne.

\footnotetext{
${ }^{53}$ I dok za ISIL i talibane postoji saglasnost većeg dela zemalja da su one terorističke organizacije, Hezbolah je sa druge strane u očima SAD, Izraela ili većih zemalja zapadne Evrope, takođe teroristička organizacija, ali za takve stavove nemaju podršku i drugih zemalja u svetu.
} 
Definisanje hibridnog rata zahteva i izdvajanje ključnih karakteristika. Mogu se izdvojiti 5 ključnih osobina hibridnog rata:

- sinhronizovanost aktivnosti

- centralizacija vođenja na strateškom nivou

- višedimenzionalnost oblika delovanja

- adaptivnost u skladu sa situacijom na terenu

- negiranje postojanja i vođenja

Sinhronizovanost aktivnosti se odnosi na usaglašenost i koordinisanost primene različitih oblika delovanja, kako bi se dobio sinergetski efekat. Ekonomski pritisci, medijska propaganda često idu uporedo sa diplomatskim pritiscima, zahtevima i sl. Vojne ili terorističke aktivnosti na terenu uglavnom su praćene i informacionim i psihološkim operacijama.

Centralizovanost vođenja je karakteristika koja se posredno može zaključiti iz sinhronizacije aktivnosti. Koordinisanost različitih oblika ugrožavanja od strane različitih nosilaca (mere obaveštajnih službi, diplomatske inicijative, medijska propaganda, dejstva vojnih jedinica), a koje su usmerene na istog protivnika, sa istim ciljem, $u$ istom vremenskom periodu, ukazuju da se oni vode iz jednog centra.

Višedimenzionalnost oblika delovanja se izvodi iz pomenutih metoda i oblasti u kojima se ispoljava hibridni rat, o čemu smo već govorili. Država ili određena zajednica, organizacija, imaju svoju strukturu, odnose, materijalne i druge vrednosti. U hibridnom ratu se ne biraju sredstva koja će se iskoristiti za napad na tu strukturu, odnose i vrednosti, pre svega ona bez upotrebe oružja, a koja mogu da omoguće dostizanje ciljeva i ostvarivanje interesa agresora.

Adaptivnost u skladu sa situacijom na terenu je dosta korišćena kod opisivanja delovanja nedržavnih aktera protiv oružanih snaga SAD i Izraela, ali i drugih primera hibridnog ratovanja. Ukazuje da se u hibridnom ratovanju mere i metode prilagođavaju protivniku, nisu unapred sve definisane i predodređene već se inoviraju zavisno od slabih tačaka protivnika, primenjuju dozirano u zavisnosti od procene da li se ciljevi agresije ostvaruju ili ne, pojačavaju novim merama ili povećanjem intenziteta do tada primenjivanih.

Negiranje postojanja $i$ vođenja hibridnog rata se izvodi iz činjenice da je većina metoda koje se primenjuju od strane agresora uglavnom neprepoznatljiva od šire javnosti kao oblik rata. Granice rata i mira u slučaju hibridnog rata su maglovite, najčešće jer se borba vodi za umove ljudi, na psihološko-vrednosnom planu. Dobar deo metoda je prikriven, subverzivan, pre svega vođen od strane obaveštajnih službi, pa se i pojedini informatički napadi, građanski protesti, oružane pobune, ne prepoznaju posredno kao delo organizovano od strane neke druge države ili sile, već imaju svoje obrazloženje za javnu upotrebu, koje služi za prikrivanje hibridnog rata. I one mere koje su javne i vidljive, kao što su ekonomske sankcije ili politički zahtevi, ne prikazuju se kao elementi hibridnog rata već kao legitimni zahtevi.

S obzirom na složenost pojave teže je dati sažetu definiciju a istovremeno obuhvatiti sve aspekte hibridnog rata. U tom smislu bi kao rešenje moglo da posluži definisanje pojma užom i širom definicijom. Uža definicija pojma bi mogla da bude sledeća: Hibridni rat predstavlja sukob dve ili više država i/ili organizacija u kome one koriste političke, ekonomske, informativne i bezbednosne elemente svoje moći, da vrše neoružanu a po potrebi i oružanu agresiju, na stanovništvo i materijalne resurse protivnika, kako bi ga potčinili svojim interesima $i$ volji. 
Šira definicija hibridnog rata bi mogla da bude sledeća: Hibridni rat predstavlja višedimenzionalni sukob u kome učestvuju jedna ili više država, i/ili organizacija formiranih na političkim, ideološkim, nacionalnim ili verskim osnovama, u okviru koga najmanje jedna strana, sa strateški centralizovanog nivoa, sinhronizovano, adaptivno, prikriveno ili javno, u okviru neoružane i oružane agresije, sprovodi informaciono-psihološko-ideološke, političke, ekonomske, obaveštajno-subverzivne, informatičke, kriminalne, terorističke i vojne aktivnosti, utičući na fizičke i mentalne resurse, društvene odnose, vrednosti i interese protivnika, a radi prisiljavanja na postupanje u skladu sa svojim političkim, ekonomskim i vojnim ciljevima i interesima.

Navedene definicije su pre svega rezultat raščlanjavanja i operacionalizacije pojma hibridni rat, na elemente koji ukazuju ko, kako, zašto, zbog čega i gde vodi hibridni rat. Definicijama se poštuju osnovna pravila definisanja, kao što su određivanje sadržaja ili bitnih karakteristika pojma, određivanja obima (skupa predmeta, nižih pojmova) kao i odnosa sa drugim pojmovima. Pojam hibridnog rata je definisan drugim pojmovima koji su jasni. I dok je uža definicija zadovoljila kriterijum sažetosti, u široj definiciji to nije moglo da se zadovolji, a u najvećoj meri je data zbog opisivanja kompleksnosti pojma hibridni rat i naglašavanja svih njegovih bitnih karakteristika. Ona dalje omogućava sistematsko ispitivanje pojma, po njegovim elementima odnosno užim pojmovima koje sadrži, pa je tako, pre svega, moguće dalje definisati pod-sadržaje oblika ugrožavanja koji se koriste u hibridnom ratu i istraživati koje se sve metode primenjuju u okviru ekonomske, informativne, obaveštajne i druge vrste agresija. Prostora ima i za opisivanje ostalih karakteristika rata, sigurno ne manje bitnih od navedenih nekoliko.

\section{Zaključak}

Istorija upotrebe pojma hibridni rat je duga svega 15-ak godina i odvijala se, a i dalje odvija, u uslovima značajnih dešavanja u svetu, kao što je početak rata protiv terorizma (nakon napada 2001. godine u SAD), rasta suprotstavljenosti između velikih sila kao što su SAD, Ruska Federacija, Kina, kretanja svetskog poretka od bipolarnog, preko unipolarnog ka multipolarnom, vođenja više manjih, regionalnih ratova. Pored toga, u određenim zemljama je dolazilo do političkih kriza, smena vlasti, protesta stanovništva, a koji su bili praćeni diplomatskim, ekonomskim pritiscima spolja, od strane većih zemalja.

Hibridni rat je kao još jedan termin u opisivanju savremenih sukoba doživeo svoje promene tokom vremena, pa se od opisivanja operativno-taktičkog nivoa borbe ne-vladinih snaga protiv većih armija, počeo koristiti na strateškom nivou za kompleksne, višedimenzionalne sukobe velikih sila ili agresije istih tih sila na manje države. Upotrebu termina je diktirao politički diskurs, pre svega u SAD i evropskim zemljama koje su članice NATO, ali se proširio i na ostatak sveta, kao poželjna tema za raspravu o ratovima današnjice i kako se oni vode. Zauzimaju se različiti stavovi o novom pojmu, ali je sigurno da on i praktično i teoretski doprinosi pozitivnom fokusu na probleme i sukobe današnjice. Može da se koristi kao merilo za određene međunarodne odnose, za ocenu nekih pojava, sačinjavanje strategija i planova odbrane, za potrebe naučnih istraživanja, itd.

Sadržaj hibridnog rata čini sukobljavanje država ili države i nevladinih entiteta, u okviru koga se primenjuje širok spektar neoružanih, po potrebi i oružanih metoda agresije, u skoro 
svim oblastima društvenog delovanja protivnika, a koje karakterišu centralizovana sinhronizacija i prilagođavanje konkretnom protivniku (otporu, uspešnosti delovanja), čiji je cilj, kao i u svakom ratu, pokoravanje i ostvarivanje političkih, ekonomskih i vojnih interesa agresora.

Obim pojma čine svi oni pojmovi na koje se pojam odnosi a za koje je analiza pokazala da obuhvata široko polje društvenog delovanja u okviru koga se hibridni rat odvija. Njegove granice čine sve one aktivnosti koje se sprovode u okviru informaciono-psihološko-ideološkog delovanja, političkih pritisaka, ekonomskog rata, obaveštajno-subverzivnih metoda, informatičkih metoda, terorizma, kriminala i vojnih operacija.

Što se tiče odnosa pojma sa drugim sličnim pojmovima, on se može posmatrati kao novi termin za već poznat sadržaj i obim ratovanja. Globalizacija, razvoj informacionih sistema, tehnologije, novih vrsta oružja, je sigurno uticao da se pojave određene nove metode i načini ugrožavanja bezbednosti, ali oni nisu uticali da se značajnije proširi pogled i teorijsko razmišljanje o oblicima delovanja u sukobu i oblastima društvenog života u okviru kojih oni mogu da se primene.

\section{Literatura}

[1] Bond S. Margaret: Hybrid War: A New Paradigm For Stability Operations In Failing States, U.S. Army War College, 2007; http://www.worldinwar.eu/wp-content/uploads /2017/09/ADA468398-1.pdf.

[2] Van Pujvelde Damien: Hybrid War - Does It even Exist?, NATO Review, Брисел, 2015, 2015; https://www.nato.int/docu/review/2015/Also-in-2015/hybrid-modern-future-warfare-russia-ukraine/EN/.

[3] Вилић Душан и Атељевић Милан: Специјални рат - одбрана и заштита, Пословна политика, Београд, 1986.

[4] Вишњић Душан: Тезе о рату, ЦВВШ ВЈ, Београд, 1994.

[5] Војник лексикон, ВИЗ, Београд, 1981.

[6] Герасимов Ваалериј: Ценность науки в предвидени, Војно-индустријски гласник, Москва, март 2013; https://vpk-news.ru/sites/default/files/pdf/ VPK_08_476.pdf.

[7] Гибридная война - Понятий, Вестник, МАГИМО Универзитет, Москва, истраживачки чланак, интервју са Офер Фридманом, професором на Краљевском колеџу у Лондону, 2016; видети више на: https://cyberleninka.ru/article/n/gibridnaya-voyna-ponyatiy.

[8] Glen Russell: Thoughts on Hybrid Conflict, Small Wars Journal, 2009; www.smallwarsjournal.com/blog/journal/.

[9] Gray Colin: How Has War Changed Since the End of the Cold War, Parameters, U.S. Army War College, 2005.

[10] Department of Defense Dictionary of Military and Associated Terms, Joint Doctrine Division, САД, 2007.

[11] Dictionary of Military and Associated Terms: Joint Publication 1-02, Министарство одбране САД, 2010 .

[12] Dodonov Roman, Kovalskyi Hryhorii, Dodonova Vera, Maryna Kolinko: Polemological Paradigm of Hybrid War Research, Philosophy and Cosmology, 19, Кијев, Украјина, 2017, стр. 2; http://ispcjournal.org/journals/2017-19/DodonovKovalskyiKolinko_19.pdf.

[13] Erdal Çayırcı, Murat Atun, Basar Kasım.: Modeling and Simulation for Hybrid Environments, NMSG Conference, Букурешт, 2016; www.sto.nato.int/ publications/.../MP-MSG-143-08P.pdf.

[14] European Commission, Joint Framework on countering hybrid threats a European Union response, Брисел, 2016; https://eur-lex.europa.eu/legal-content/EN/TXT/?uri =CELEX:52016JC0018. 
[15] Интернет страница: www.merriam-webster.com/dictionary/hybrid.

[16] Интернет страница: Wikipedia, bs.wikipedia.org/wiki/Spisak_ratova.

[17] Интернет страница: http://www.dictionary.com/browse/war?s=t.

[18] Jan Jacub U.: United in Ambiguity? EU and NATO Approaches to Hybrid Warfare and Hybrid Threats, College of Europe, Бриж, Белгија, 2017: Tenenbaum E.: Le piège de la guerre hybride, Focus stratégique, Institut Français des Relations Internationales, 2015.

[19] JCS Publication, Министарство одбране САД, Вашингтон, јануар, 1972.

[20] Јовановић Владан: Српска војна лексика и терминологија, Институт за српски језик САНУ, Београд, 2016.

[21] Ковач Митар и Форца Божидар: Историја ратне вештине (1920-2000), ВИЗ, Београд, 2000.

[22] Ковач Митар, Стојковић Дејан: Стратегијско планирање одбране, ВИЗ, Београд, 2009.

[23] Корибко Андреј: Hybrid Wars: The Indirect Adaptive Approach To Regime Change, Народни универзитет Русије, Москва, 2015;

https://orientalreview.org/wp-content/uploads/2015/08/AK-Hybrid-Warsupdated.pdf.

[24 Kaldor Mary: Old Wars, Cold Wars, New Wars, and the War on Terror, International Politics, Лондон, 2005; www.academia.edu/3444310/Old_Wars_Cold_Wars_New_Wars_and_the_War_on_Terror

[25] Klauzevic fon Karl.: O рату, Војно дело, Београд, 1951.

[26] Kříž Zdeněk, Bechná Zinaida, Števkov Peter: Hybrid warfare: its concept, potential and how to fight it, чланак у публикацији Hybrid Warfare: A New Phenomenon in Europe's Security Environment, Jagello 2000, Праг, 2015; http://data.idnes.cz/ soubory/na_knihovna/A161212_M02_029_HH16_PP-EN V1.PDF.

[27] Lasconjarias Guillaume, Larsen Jeffrey.: Nato's response to hybrid threat, NATO Defense College, 2015.

[28] Lind William, Keith Nightengale, John F. Schmitt, Joseph Sutton $и$ Gary Wilso: The Changing Face of War: Into the Fourth Generation, Marine Corps Gazzete, Вашингон, 1989; www.mca-marines.org.

[29] Марковић Михајло: Логика, Завод за уџбенике и наставна средства, Београд, 1994.

[30] Mattis James, Hoffman Frank: Future Warfare: The Rise of Hybrid Wars, Proceedings 131, 11, Вашингтон, 2005.

[31] Микић Слободан: Поглед на рат, Војна академија, Војноиздавачки завод, Београд, 2003.

[32] Мирковић Тодор: Циљеви, форме и средства економског рата, Војна економска академија, Београд, 1971.

[33] McCulloh Timothy, Johnson Richard: The Nature of Hybrid Warfare: Built to Last, Joint Special Operations University Report,2013;

http://www.socom.mil/JSOU/JSOUPublications/JSOU\%20134_McCulloh,Johnson_Hybrid\%20Warf are_final.pdf

[34] Murray Williamson и Mansoor Peter: Hybrid Warfare: Fighting Complex Opponents from the Ancient World to the Present, Cambridge University Press, New York, 2012.

[35] Munich Security Report 2015, Munich Security Conference, Минхен, 2015; https://www.securityconference.de/fileadmin/MunichSecurityReport/MunichSecurityReport_2015.pdf.

[36] Mueller R.: Why the US Needs a Strategy To Counter 'Hybrid Warfare, The U.S. Army Special Operations Command (USASOC), 2014; https://www.defenseone.com/ideas/ 2014/10/why-us-needsstrategy-counter-hybridwarfare /97259/.

[37] Nemeth William.: Future war and Chechnya: a case for hybrid warfare, Naval Postgraduate School, Monterey, California, 2002; https://calhoun. nps.edu/bitstream/handle/10945/5865/02Jun_Nemeth.pdf

[38] Olson Wiliam: The Light Force Initiative, Military Review, jyн 1985. 
[39] Операције психолошког рата, амерички војни приручник, ФМ 33-5, 1962.

[40] Pindjak Peter: Deterring hybrid warfare: a chance for NATO and the EU to work together?, NATO Review, 18, Брисел,2014; https://www.nato.int/docu/review/2014/Also-in-2014/Deterringhybridwarfare/EN/ index.htm.

[41] Политичка енциклопедија, Савремена администрација, Београд, 1975.

[42] Reichborn-Kjennerud Eric, Cullen Patrick: What is hybrid war?, Policy brief, Норвешки Институт за међународне послове, 2016;

www.brage.bibsys.no/xmlui/bitstream/id/411369/NUPI_PolicyBrief1Reichborn_Kjennerud_Cullen.pdf

[43] Ротмистров Павел, Историја ратне вештине 1, ВИЗ, Београд, 1996.

[44] Речник српског језика, Матица српска, Нови Сад, 2011.

[45] Социолошки лексикон, Савремена администрација, Београд, 1982.

[46] Стратегија оружане борбе, ССНО, Београд, 1983.

[47] Smith Rupert: The Utility of Force: The Art of War in the Modern War, Allen Lane, Лондон, 2005; https://en.wikipedia.org/wiki/The_Utility_of_Force.

[48] Суштина функција и организација психолошког рата, ССНО, Београд, 1966.

[49] Сун Тзу: Умеће ратовања; www.globalbook.rs/uploads/1/1/3/2/11327145/ sun_tzu__umece_ratovanja.pdf

[50] Stoltenberg Jan: „Zero-Sum? Russia, Power Politics, and the post-Cold War Era", Brussels Forum, 2015; https://www.nato.int/cps/su/ natohq/opinions_118347.htm)

[51] Understanding Hybrid Warfare, MCDC /Multinational Capability Development Campaign project/,САД,2017;

https://assets.publishing.service.gov.uk/government/ uploads/system/uploads/attachment data/ file / 647776/dar_mcdc_hybrid_warfare.pdf

[52] Field Manual 5-0: The Operations Process, Headquarters, Department of the Army, Washington, 2011.

[53] Field Manual 3-0: The Operations Process, Headquarters, Department of the Army, Washington, 2011.

[54] Fukujama Francis: End of history and last man, The free press, Macmillan, New York, 1992.

[55] Future Character of Conflict, HQ Land Forces, Министарство одбране Велике Британије, Лондон, 2010.

[56] Herfried Münkler: Hybrid Wars: The Dissolution of the Binary Order of War and Peace, and Its Consequences, Ethics and Armed Forces, 2015.

[57] Hoffman Frank: Conflict in the 21st Century: the Rise of Hybrid Wars, Potomac Institute for Policy Studies, Arlington, Virginia, 2007;

www.potomacinstitute. org/images/stories/publications/potomac_hybridwar_0108.pdf

[58] Huber Thomas: Compound warfare: That Fatal Knot, U.S. Army Command and General Staff College Press, Канзас, САД, 2002.;;//cgsc.contentdm.oclc.org/ cdm/ref/collection/p16040coll3/id/75.

[59] Шарановић Јованка, Фулетић Ђуро, Николић Милојко, Јеремић Златан: Историја ратне вештине - период до 1920, ВЗИ, Београд, 2000.

[60] Qiao Liang u Wang Xiangsui: Unrestricted Warfare: China's Master Plan to Destroy America, Pan American Publishing Company, Лос Анђелес, 2002, 1999. у Кини; http://www.c4i.org/unrestricted.pdf

[61] Quadrennial Defense Review, Министарство одбране САД, Вашингтон, 2010,8; https://www.defense.gov/Portals/1/features/defenseReviews/QDR/QDR_as_of_29JAN10_1600.pdf

[62] Wales Summit Declaration, NATO, Велс, 2014; www.nato.int/cps/en/natohq/ official_texts_12964.htm 